\title{
栗DZIEDZICTWO GEOLOGICZNE
}

\section{Walory geoedukacyjne i geoturystyczne kamieniołomu Zygmuntówka na Czerwonej Górze (Góry Świętokrzyskie)}

\author{
Karol Jewuła $^{1}$, Anna Fijalkowska-Mader ${ }^{1}$, Sylwester Salwa ${ }^{2}$
}

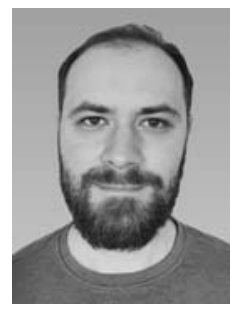

K. Jewuła

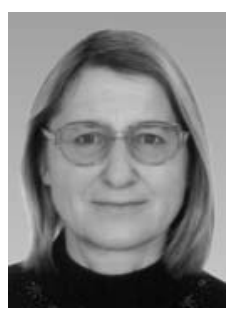

A. Fijałkowska-Mader

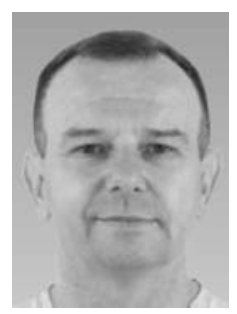

S. Salwa

Geoeducational and geotourist value of the Zygmuntówka (Sigismund) quarry at Czerwona Góra (Holy Cross Mountains). Prz. Geol., 70: 25-33; doi: $10.7306 / 2022.1$

A b s t r a c t. The geosite Zygmuntówka (Sigismund) quarry, located at Czerwona Góra near Chęciny in SW part of the Holy Cross Mountains, is the oldest and the most famous among the so-called Checiny "marble" quarries which provided stones for constructing numerous important buildings in the region and beyond. Upper Permian conglomerates (Czerwona Góra Formation), with a thickness of several tens of metres, outcrop in this area. The conglomerates are clast- and locally mud-supported and consist of light grey and beige carbonate pebbles and cobbles chaotically distributed within the reddish-brown silty-carbonate-ferriferous matrix. The conglomerates represent continental alluvial fan deposits deposited under arid and semiarid climate conditions. The quarry, of a regional rank, is well suited for both geoeducation and geotourism purposes.

Keywords: Zygmuntówka quarry, conglomerates, Upper Permian-Lopingian, geoeducation

Kamieniołom Zygmuntówka, w starszej literaturze zwany też Jerzmańcem, znajduje się w środkowej części Pasma Bolechowickiego, na południowym zboczu Czerwonej Góry, ok. $10 \mathrm{~km}$ na południowy zachód od Kielc i $3 \mathrm{~km}$ na północny wschód od Chęcin (tab. 1, ryc. 1). W jego bezpośrednim sąsiedztwie przebiega czerwony szlak turystyczny, prowadzący z Kielc do Chęcin. W kamieniołomie tym odsłaniają się permskie zlepieńce, które od wieków stanowiły ważne źródło kamienia dla lokalnego oraz krajowego budownictwa, zajmując poczesne miejsce wśród tzw. marmurów chęcińskich, zwanych też kieleckimi. Jako kamień dekoracyjny zlepieniec ten charakteryzuje się czerwono-brązową barwą spoiwa, w którym tkwią różnobarwne otoczaki - głównie dewońskich skał węglanowych. W związku z tą wyjątkową kolorystyką kamieniarze nazwali go mało elegancko salcesonem, co w żaden sposób nie umniejsza jego bardzo dobrych właściwości geotechnicznych i dużej atrakcyjności wizualnej. Eksploatacja tego surowca zaczęła się już w czasach I Rzeczypospolitej. W latach 1642-1644 wykonano z niego pierwszą kolumnę Zygmunta III Wazy, postawiona na placu Zamkowym w Warszawie. To właśnie od tej kolumny pochodzi nazwa zlepieńca i kamieniołomu. Elementy architektoniczne wykonane ze zlepieńca zygmuntowskiego można spotkać w wielu kościołach na terenie dzisiejszej Polski, a także poza jej granicami: na Litwie, Ukrainie, Węgrzech czy w Rumunii, oraz w budowlach świeckich, np. na zamku wawelskim, w pałacu w Wilanowie czy w pałacu biskupów krakowskich w Kielcach. Są to głównie kolumny, portale, płyty posadzkowe i tablice inskrypcyjne (Wardzyński, 2011,
2014). Pod koniec XIX w. i na początku XX w. zlepieniec zygmuntowski wraz z innymi ,marmurami” chęcińskimi odrywał ważną rolę w promocji gospodarczej regionu, o czym świadczą liczne publikacje (m.in. Welke, 1873; Święcicki, 1874; Jenike, 1878; Choroszewski, 1893; Kontkiewicz, 1910). Marmur ten powszechnie wykorzystywano w okresie międzywojennym, jak np. w budynku głównym Akademii Górniczo-Hutniczej w Krakowie (Rajchel, 2005), Dworca Kolejowego w Gdyni czy Wojewódzkiego Domu Kultury w Kielcach. Podczas odbudowy kraju po zniszczeniach spowodowanych drugą wojną światową nastapił wzrost zapotrzebowania na elementy architektoniczne wykonane ze zlepieńca zygmuntowskiego (Oterman, 1980). Surowiec ten był także wykorzystywany w okresie późniejszym, np. do ozdobienia hotelu Cracovia w Krakowie z 1965 r. (Rajchel, 2005).

Celem niniejszego artykułu jest przedstawienie geostanowiska Czerwona Góra, miejsca o wyjątkowych walorach geoedukacyjnych i geoturystycznych, które umożliwia poznanie szczególnego środowiska późnopermskiej, lądowej sedymentacji, jaka zachodziła w warunkach klimatu suchego oraz półsuchego.

\section{TLO GEOLOGICZNE}

Kamieniołom Zygmuntówka został założony w północnym skrzydle synkliny gałęzicko-bolechowickiej, która należy do regionu kieleckiego, będącego południowym segmentem paleozoicznego trzonu Gór Świętokrzyskich (Czarnocki, 1950). Synklinę tę tworzą w głównej mierze

\footnotetext{
${ }^{1}$ Instytut Nauk Geologicznych PAN, ul Senacka 1, 31-002 Kraków; k.jewula@ingpan.krakow.pl

2 Państwowy Instytut Geologiczny - Państwowy Instytut Badawczy, Oddział Swiętokrzyski, ul. Zgoda 21, 25-953 Kielce; anna.mader@pgi.gov.pl; sylwester.salwa@pgi.gov.pl
} 
Tab. 1. Podstawowe dane o stanowisku geologicznym (geostanowisku) kamieniołom Zygmuntówka Table 1. Basic data on the geosite Zygmuntówka (Sigismundus) quarry

\begin{tabular}{|l|l|}
\hline Nazwa miejscowości / Locality & Czerwona Góra k. Chęcin \\
\hline $\begin{array}{l}\text { Nr karty dokumentacyjnej geostanowiska w CRGP } \\
\text { Geosite reference number }\end{array}$ & 868 \\
\hline Współrzędne GPS / GPS Coordinates & $\mathrm{N}: 50^{\circ} 49^{\prime} 06,20^{\prime \prime} \mathrm{E}: 20^{\circ} 29^{\prime} 47,00^{\prime \prime}$ \\
\hline Wysokość n.p.m. / Altitude m a. s. l. & 295 \\
\hline Typ odsłonięcia / Type of the outcrop & sztuczne / artificial \\
\hline Forma własności / Owner & własność prywatna / private \\
\hline Dostępność / Accessibility & łatwa / easy \\
\hline $\begin{array}{l}\text { Typ geostanowiska (wg Alexandrowicz, 2006) } \\
\text { Geosite type (according to Alexandrowicz, 2006) }\end{array}$ & C, D, F, G, H \\
\hline Forma ochrony / Conservation status & brak / none \\
\hline $\begin{array}{l}\text { Wiek skał (chrono- i litostratygrafia) } \\
\text { Age of rocks (chrono- and lithostratigraphy) }\end{array}$ & $\begin{array}{l}\text { górny perm - loping; cechsztyn, formacja z Czerwonej Góry } \\
\text { upper Permian - Lopingian, Zechstein, Czerwona Góra Formation }\end{array}$ \\
\hline Wiek procesów geologicznych / Age of geological processes & późny perm, wczesny trias, paleogen / Late Permian, Early Triassic, Paleogene \\
\hline Litologia / Lithology & zlepieńce / conglomerates \\
\hline Skamieniałości / Fossils & brak / none \\
\hline Geneza skał / Rocks origin & $\begin{array}{l}\text { lądowe stożki aluwialne, osad roztworów hydrotermalnych, brekcja tektoniczna } \\
\text { continental alluvial fans, hydrothermal fluids circulation deposits, tectonic breccia }\end{array}$ \\
\hline $\begin{array}{l}\text { Geneza form morfologicznych } \\
\text { Origin of geomorphological forms }\end{array}$ & krasowa / karst \\
\hline
\end{tabular}

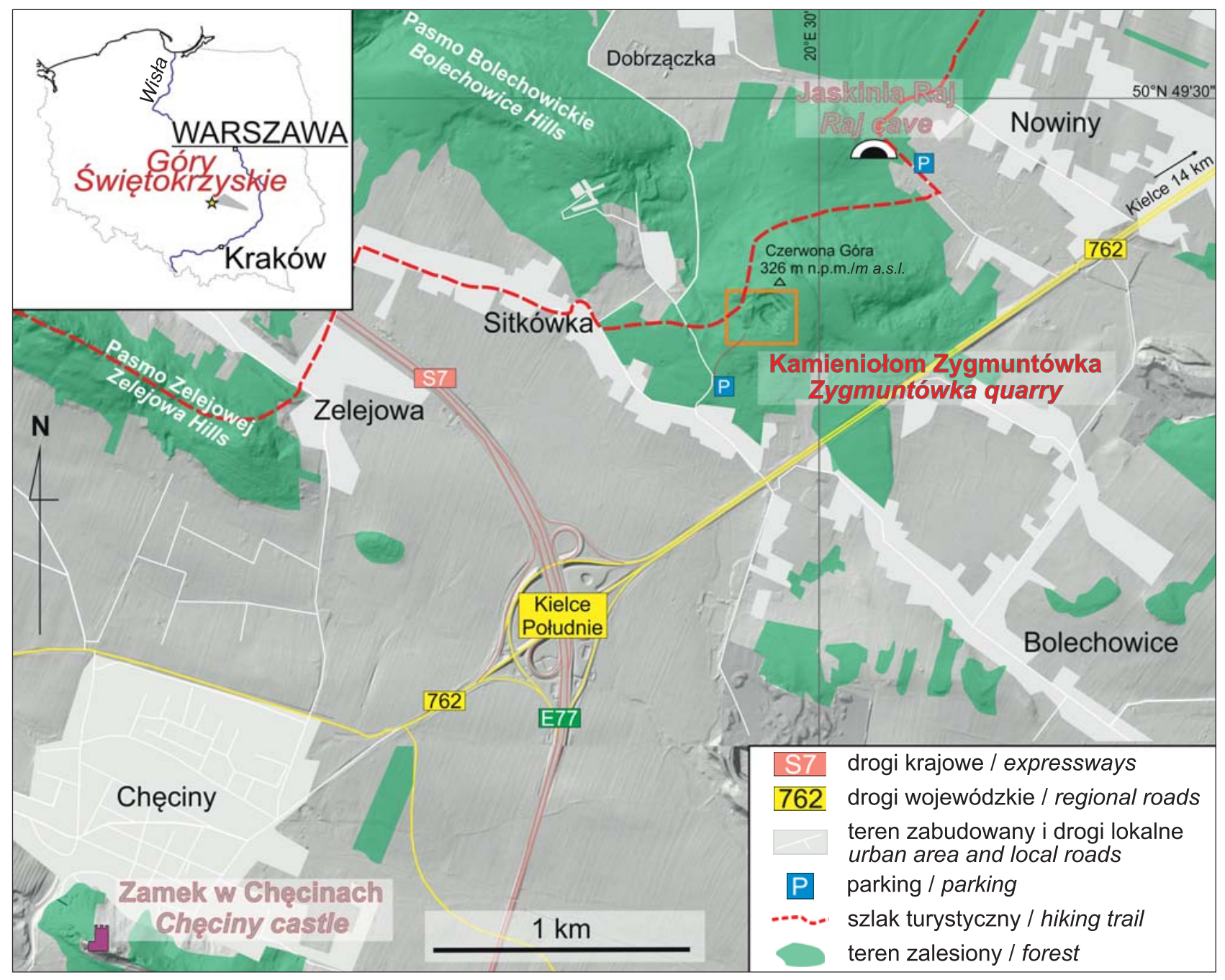

Ryc. 1. Lokalizacja kamieniołomu Zygmuntówka

Fig. 1. Location of the Zygmuntówka (Sigismund) quarry 
skały dewońskie i karbońskie, które zostały sfałdowane w trakcie orogenezy waryscyjskiej (Szulczewski, 1995). Erozja, która nastąpiła po zakończeniu ruchów fałdowych, doprowadziła do znacznego wyrównania powierzchni terenu, przygotowując niejako miejsce do depozycji permskich zlepieńców. Skład zlepieńców wykazuje ścisły związek z litologią osadów występujących w ich podłożu i bezpośrednim otoczeniu, dlatego zlepieńce te charakteryzują się znaczną zmiennością w zależności od miejsca występowania (Kowalczewski, Rup, 1989).

Zlepieńce zygmuntowskie były przedmiotem badań geologów już w pierwszej połowie XIX w. Brak skamieniałości oraz fakt, że zlepieńce te i odpowiadające im wiekowo skały okruchowe nie tworzą ciagłej pokrywy, lecz występują w formie płatów leżących na starszych, sfałdowanych skałach (Czarnocki, 1950; Kowalczewski, Rup, 1989), od początku utrudniał jednoznaczne określenie ich wieku. Pusch (1836) zaliczył je do dewonu i dopiero w drugiej połowie XIX w. skały te uznano za młodsze (permskie) osady czerwonego spagowca (Roemer, 1870; Michalski, 1887; Gürich, 1896) bądź jeszcze młodsze utwory dolnego triasu (Sobolew, 1911; Czarnocki, Samsonowicz, 1915; Siemiradzki, 1922). W rejonie Gałęzic, oddalonych o ok. 6 km na NW od Czerwonej Góry, Czarnocki (1916, 1923) stwierdził w tych zlepieńcach, które nazywał zygmuntowskimi, obecność ramienionogów Productus horridus Sowerby (obecnie Horridonia horrida). Na tej podstawie zaliczył zlepieńce zygmuntowskie do cechsztynu. Po II wojnie światowej perm świętokrzyski (w tym zlepieńce zygmuntowskie) był przedmiotem badań Kosteckiej (1962, 1966), Głazka i Romanka (1978), Kowalczewskiego i Rup (1989) oraz Bełki (1991). Istotny wkład w poznanie genezy zlepieńców wniosły badania sedymentologiczne Kulety i Zbroi (1998). Ostatnie prace dotyczące stratygrafii i sedymentologii tych osadów opublikował Jewuła i in. (2020, 2021).

W otworach wiertniczych zlokalizowanych w synklinie gałęzicko-bolechowickiej, synklinie piekoszowskiej oraz w rejonie Kajetanowa wyróżniono dwa kompleksy zlepieńców, tzw. zlepieniec dolny oraz górny. Są one rozdzielone utworami morskimi i lądowymi cechsztynu (Szaniawski, 1963; Kostecka, 1966; Rubinowski, 1978). Skład obu kompleksów różni się nieco od siebie. W dolnym zlepieńcu obok skał węglanowych dewonu występują także piaskowce dewońskie i skały kambryjskie, a otoczaki charakteryzują się zmienną wielkością i zróżnicowanym stopniem obtoczenia. W nielicznych wkładkach węglanowych tkwią skorupy małży morskich z gatunku Horridonia horrida (Czarnocki, 1948; Czarniecki i in., 1965; Kaźmierczak, 1967), które wskazywałyby na rozwój wybrzeża typu riasowego (Kostecka, 1966). Zlepieńce górne są pozbawione fauny i charakteryzują się bardziej ujednoliconym składem otoczaków, wśród których dominują wapienie żywetu, ale są obecne także redeponowane fragmenty starszych konglomeratów oraz okruchy cechsztyńskich skał węglanowych (Kostecka, 1962). Zgodnie z najnowszą propozycją litostratygrafii pogranicza permu i triasu (Jewuła i in., 2020) zarówno zlepieńce dolne, jak i górne wchodzą w skład formacji z Czerwonej Góry, zazębiającej się lateralnie $\mathrm{z}$ osadami cechsztynu: PZ1-PZt, tj. formacją mułowców oraz piaskowców z Podzamcza i formacją mułowców oraz piaskowców z paleoglebami z Siodeł. Zlepieńce zygmuntowskie z Czerwonej Góry są korelowane z kompleksem zlepieńca górnego i odpowiadają cyklotemom PZ4-PZt (ryc. 2; Kuleta i in., 2007).

Geneza zlepieńców od początku badań budziła kontrowersje. Czarnocki (1948) sugerował przerabianie cechsztyńskich zwietrzelin w środowisku morskim bądź depozycję zlepieńców na lądzie. Kostecka (1966) interpretowała pakiety zlepieńców jako osady rzeczne oraz podkreślała istotną rolę procesów tektonicznych w odmłodzeniu rzeźby terenu w późnym permie. Inną genezę zlepieńców przedstawili Zbroja i in. (1998) oraz Kuleta i in. (2007). Na podstawie występowania wkładek utworów morskich w zlepieńcach zygmuntowskich (np. w otworze Białe Zagłębie B-1) oraz danych izotopowych autorzy owi przyjęli, że są one osadem delty stożkowej, wkraczającej do cechsztyńskiej zatoki morskiej. W opublikowanej ostatnio analizie sedymentologicznej cechsztynu świętokrzyskiego Jewuła i in. (2020, 2021) uznali zlepieńce formacji z Czerwonej Góry za osady stożkówstożków koluwialnych, rozwiniętych u podnóża wynoszonych bloków dewońskich skał węglanowych (zob. także Kozłowska, 2012). Występowanie licznych, synsedymentacyjnych struktur tektonicznych w osadach górnego permu, stwierdzonych w otworach zlokalizowanych w pobliżu kamieniołomu Zygmuntówka, oraz zróżnicowanie stopnia rozwinięcia pokryw paleoglebowych w tych osadach (formacje z Podzamcza oraz z Siodeł), wskazuje na mobilność tektoniczną (Szulc, 2015) oraz okresowe odmładzanie rzeźby (por. Kostecka, 1966; Kowalczewski, Rup, 1989), prowadzących do zwiększonego nachylenia terenu, co powodowało wzmożenie erozji oraz depozycję osadów gruboziarnistych.

Rejon świętokrzyski znajdował się pod koniec permu na SE peryferiach basenu cechsztyńskiego, w północnej części superkontynentu Pangea, w strefie zwrotnikowej (Ziegler, 1989; Wagner, 1994). Depozycja zlepieńców zygmuntowskich zachodziła w warunkach klimatu suchego i gorącego. Dominującym jej mechanizmem były niekohezyjne oraz kohezyjne spływy grawitacyjne o zróżnicowanej mechanice spływu - reologii (Zbroja i in., 1998; Żuk i in., 2018). Procesy te doprowadzily do powstania bezstrukturalnych zlepieńców o zwartym bądź rozproszonym szkielecie ziarnowym (Zbroja i in., 1998; Jewuła i in., 2021).

Ruchy tektoniczne związane z postwaryscyjską aktywnością tektoniczną (Kutek, Głazek, 1972; Głazek, Romanek, 1978; Migaszewski, Mader, 2019) kontrolowały tempo i warunki sedymentacji w basenie cechsztyńskim (Wagner, 1988). Miały one ponadto wpływ na mineralizację kalcytową i kruszcową, powszechnie występującą w zlepieńcach (Rubinowski, 1971, 1978).

\section{HISTORIA WYDOBYCIA ZLEPIEŃCA ZYGMUNTOWSKIEGO}

Ponad 400-letnia historia eksploatacji kamieniołomu Zygmuntówka sprawia, że należy on do najstarszych kamieniołomów w regionie świętokrzyskim. Udokumentowane początki pozyskiwania zlepieńca zygmuntowskiego sięgają XVI w. Z kamienia tego jest wykonana płyta epitafijna w przedsionku kieleckiej bazyliki katedralnej, która pochodzi z 1583 r., także portale w apartamencie króla Zygmunta III Wazy na Wawelu - z lat 1598-1603 (Wardzyński, 2011). Fakt, że już w 1607 r. było możliwe wykonanie trzonu kolumny króla Zygmunta III Wazy z jednego bloku skalnego o średnicy około 1 metra i długości 11,6 m (Rajchel, 


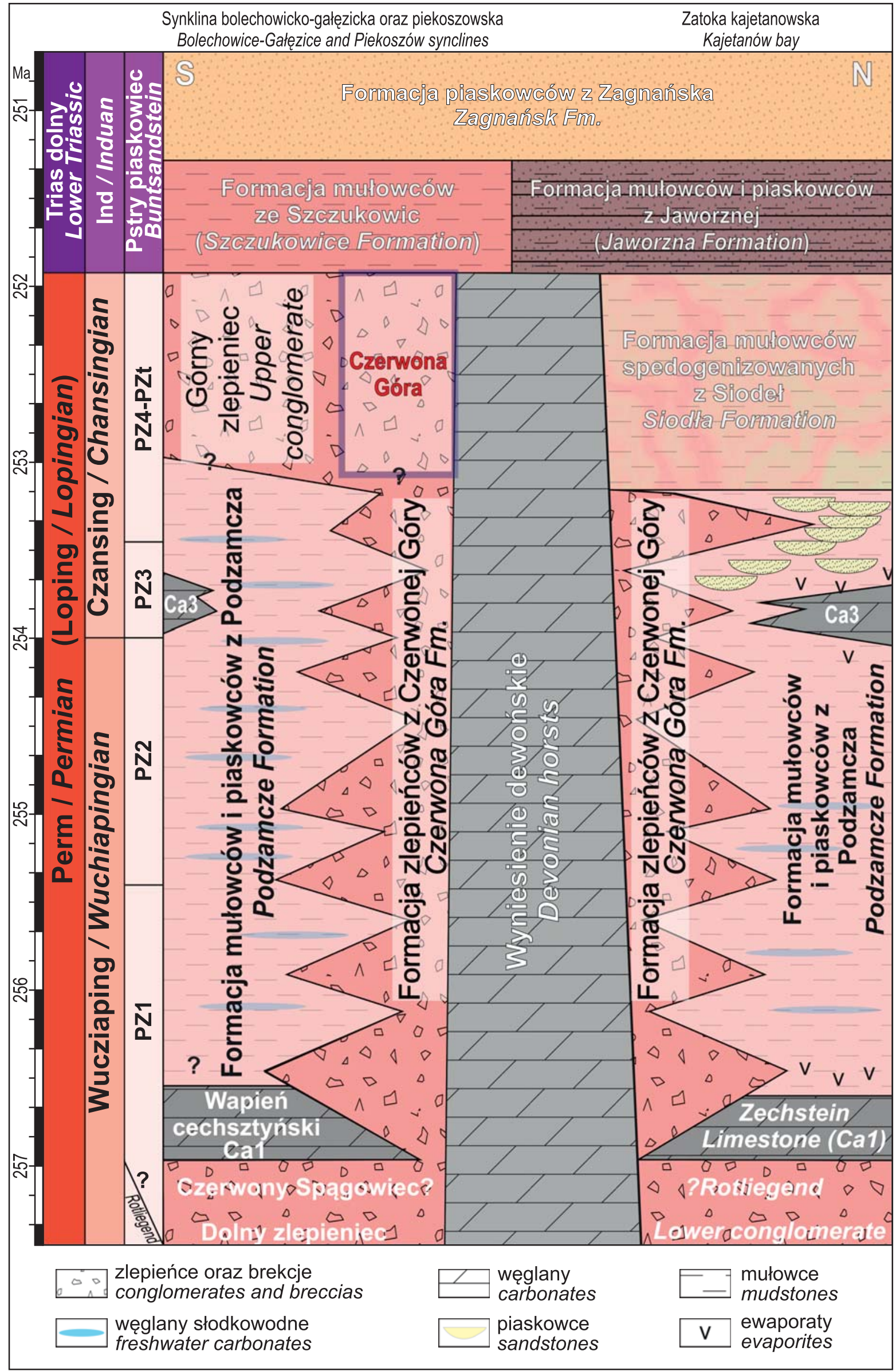

Ryc. 2. Uproszczona litostratygrafia górnego permu NW obrzeżenia Gór Świętokrzyskich: Ca3 - dolomit płytowy

Fig. 2. Simplified lithostratigraphy of the Upper Permian from the NW part of the Holy Cross Mountains: Ca3 - Platy Dolo- 
2005), świadczy o wielkości samego marmurołomu. W okresie potopu szwedzkiego nastąpiło znaczne zmniejszenie wydobycia zlepieńca, a pod koniec XVIII w. zamknięto ośrodek kamieniarski w Chęcinach i przerwano wydobycie tej skały aż do lat 70. XIX w. (Wardzyński, 2014). Eksploatację zlepieńca i jego obróbkę wznowiło Przedsiębiorstwo Kopalń Marmurów Kieleckich, zwane później Marmurami Kieleckimi, które z przerwami użytkowało złoże do 1973 r. (Gagol i in., 2017, 2020), a następnie przekazało je Pińczowskim Zakładom Kamienia Budowlanego. Od tego momentu wydobycie surowca sukcesywnie malało.

Do lat 30. XX w. zlepieńce były wydobywane i obrabiane metodami ręcznymi, co pozwalało oszczędzać złoże i dostarczało niewielkiej ilości odpadów. Mechanizacja wydobycia po drugiej wojnie światowej oraz użycie do tego celu materiałów wybuchowych spowodowały w dużej mierze zniszczenie naturalnej bloczności skały, a co za tym idzie, pozyskiwano coraz mniejsze bloki i powstawało coraz więcej odpadów. Ostatecznie eksploatację zakończono w 1993 r., ze względu na konieczność ochrony pobliskiej jaskini Raj (Rubinowski, Szlagowski, 1981).

\section{OPIS GEOSTANOWISKA}

Kamieniołom Zygmuntówka jest dużym wyrobiskiem stokowo-wgłębnym, półkolistego kształtu, o średnicy ok. $200 \mathrm{~m}$ i głębokości $30 \mathrm{~m}$. Odsłania się w nim profil gruboławicowych zlepieńców oraz podrzędnie gruboziarnistych piaskowców (ryc. 3). Zlepieńce były wydobywane na trzech poziomach eksploatacyjnych; wysokość ścian wyrobisk wynosiła od 10 do 15 m (ryc. 4). Cały kompleks skalny zapada pod kątem ok. $10^{\circ} \mathrm{w}$ kierunku południowo-wschodnim. Uławicenie jest na ogół słabo widoczne, natomiast dobrze zaznaczają się w skałach spękania ciosowe. Ich obecność ułatwiała w przeszłości pozyskiwanie dużych, regularnych bloków skały. Miąższość warstw zlepieńców jest zróżnicowana (od 1 do $6 \mathrm{~m}$ ), a granice między nimi są erozyjne.

Cała sekwencja jest reprezentowana przez czerwony, różowy bądź brązowokremowy zlepieniec składający się ze średnio- do bardzo dobrze obtoczonych, jasnoszarych i beżowych otoczaków i okruchów dewońskich skał węglanowych - wapieni, a także mniej licznych dolomitów. Otoczaki mają różną wielkość, od kilku do kilkunastu $\mathrm{cm}$, a niekiedy nawet do $1 \mathrm{~m}$. Szkielet ziarnowy jest przeważnie zwarty oraz dobrze upakowany (ryc. 5), choć miejscami występują także zlepieńce o szkielecie rozproszonym (ryc. 6). Okruchy stykają się ze sobą punktowo, ale stwierdza się także obecność kontaktów suturowych. Dominuje spoiwo ilasto-weglanowo-żelaziste barwy czerwono-brunatnej (ryc. 6). Zlepieniec odznacza się złym wysortowaniem i chaotycznym rozmieszczeniem otoczaków, a jedynie lokalnie zaznacza się gradacja uziarnienia (ryc. 7). W górnej części kamieniołomu miejscami jest widoczna również imbrykacja okruchów. Niektóre ławice wykazują warstwowanie poziome, głównie w środkowej części profilu, a w jego górnej części można znaleźć także ławice $\mathrm{z}$ warstwowaniem przekątnym rynnowym (por. Zbroja i in., 1998; Żuk i in., 2018).

$\mathrm{W}$ zlepieńcach $\mathrm{z}$ kamieniołomu Zygmuntówka są obecne liczne i zróżnicowane żyły mineralne, przecinające skały. Głównie są to syntaksjalne żyły kalcytowe kilku generacji, w tym także żyły typu różanka (patrz zdjęcie na

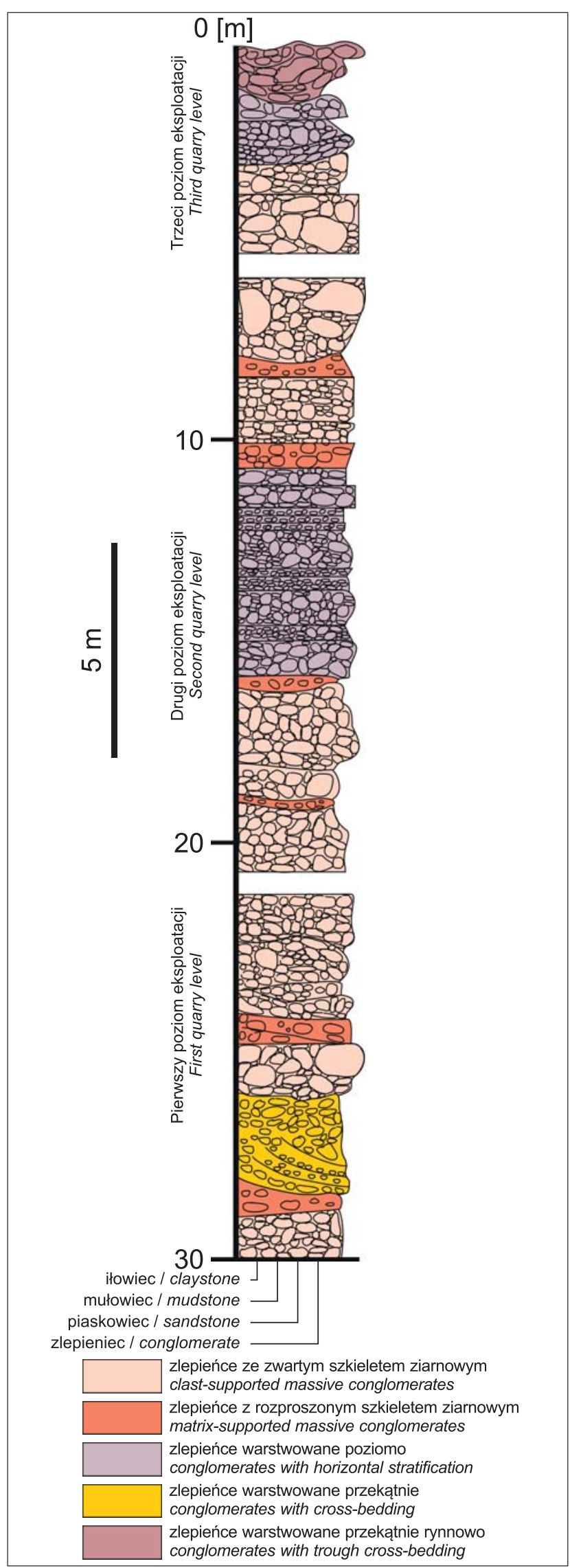

Ryc. 3. Profil litologiczny zlepieńca zygmuntowskiego (formacja zlepieńców z Czerwonej Góry) w kamieniołomie Zygmuntówka (wg Zbroi i in., 1998, zmieniony)

Fig. 3. Lithological profile of Zygmuntówka conglomerates (Czerwona Góra Formation) in Zygmuntówka quarry (after Zbroja et al., 1998, modified) 
okładce), a znaczna ich część wykazuje uporządkowanie przestrzenne, spowodowane zabliźnianiem przez nie, otwartych uprzednio, spękań ciosowych (Migaszewski i in., 1996). Żyły osiągają długość do kilkudziesięciu metrów, a ich miąższość przekracza $0,5 \mathrm{~m}$. Kalcyt, z którego się składają, ma pokrój grubokrystaliczny. Częste są także kawerny z dobrze wykształconymi kryształami. W żyłach obok kalcytu występuje także baryt oraz minerały kruszcowe - głównie galena, ale także piryt i chalkopiryt. Galena była w przeszłości przedmiotem eksploatacji górniczej na

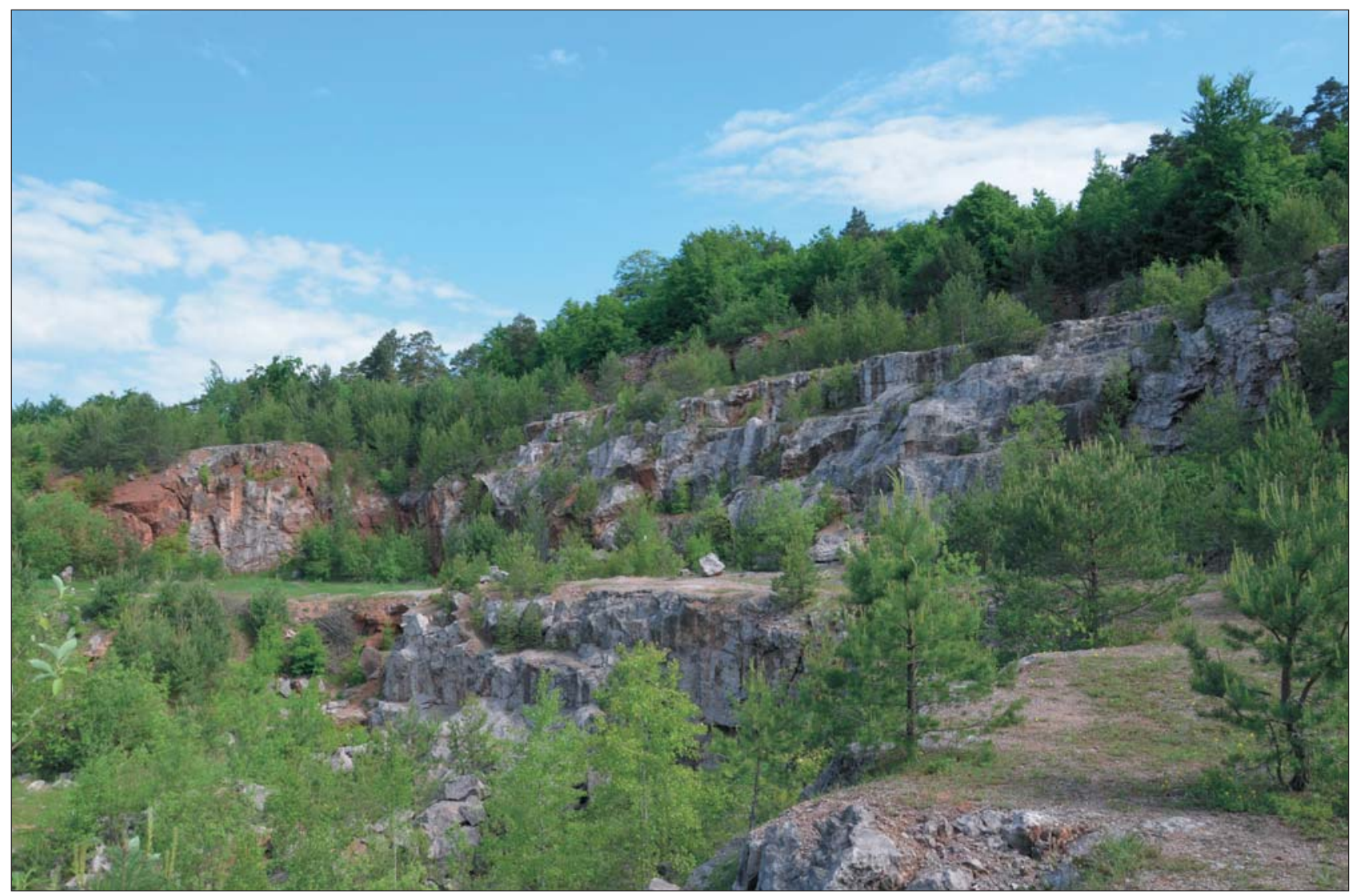

Ryc. 4. Panorama kamieniołomu Zygmuntówka. Fot. J. Malec

Fig. 4. Overview of the Zygmuntówka quarry. Photo by J. Malec
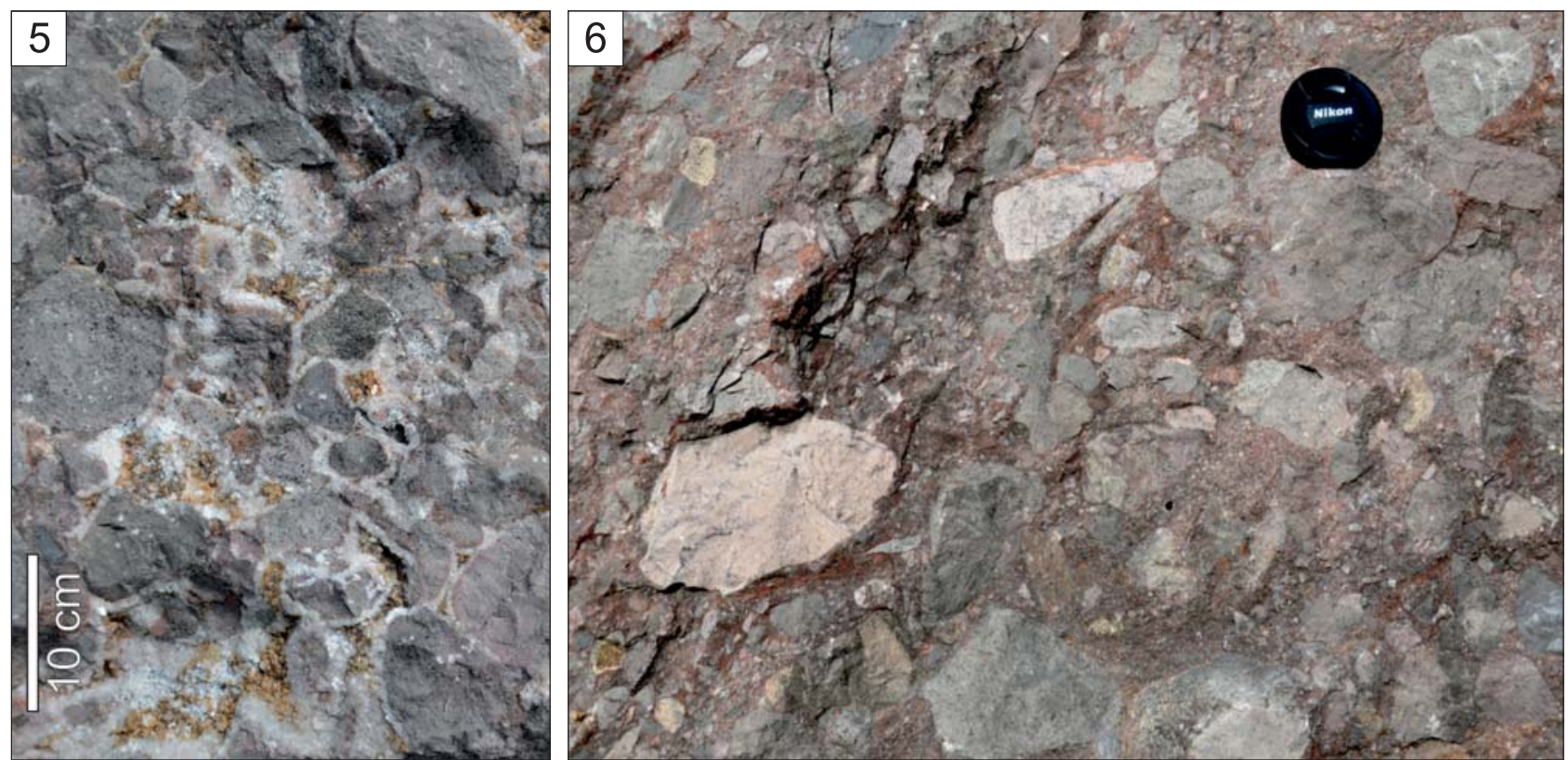

Ryc. 5. Zlepieniec o zwartym szkielecie ziarnowym. Wokół klastów są widoczne otoczki białego, wtórnego kalcytu. Fot. K. Jewuła Fig. 5. Clast-supported conglomerate. Visible white fringes of secondary calcite around the clasts. Photo by. K. Jewuła

Ryc. 6. Zlepieniec zygmuntowski o rozproszonym szkielecie ziarnowym. Fot. A. Mader

Fig. 6. Matrix-supported Zygmuntówka conglomerate. Photo by A. Mader 

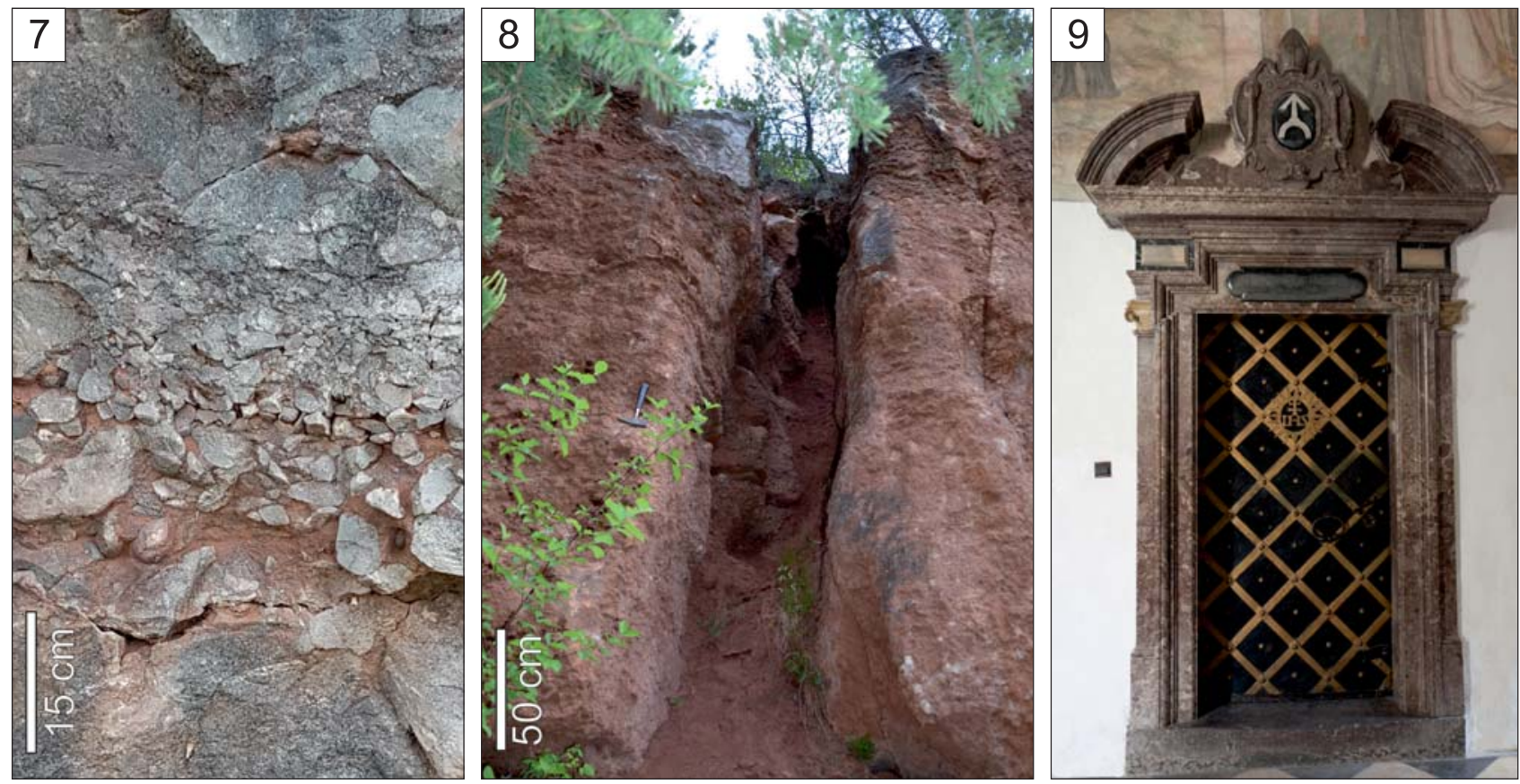

Ryc. 7. Przykład zróżnicowanego upakowania klastów w zlepieńcu oraz słabo zaznaczającej się gradacji ich wielkości. Fot. K. Jewuła Fig. 7. An example of various degrees of clast packing in the conglomerates. Note poorly developed normal clast-size gradation. Photo by. K. Jewuła

Fig. 8. Szczelina krasowa w górnej części kamieniołomu. Fot. J. Malec

Fig. 8. Karst in the upper part of the quarry. Fot. J. Malec

Ryc. 9. Siedemnastowieczny portal wykonany ze zlepieńca zygmuntowskiego, zdobiący wejście do zakrystii w klasztorze na Łysej Górze. Fot. D. Szrek

Fig. 9. $17^{\text {th }}$-century portal made of the Sigismund conglomerate around the door to the sacristy in the monastery on Mt Łysa Góra. Photo by D. Szrek

znaczącą skalę (Rubinowski, 1971). Resztki wyrobisk były odsłaniane w trakcie eksploatacji kamieniołomu i ciagle są widoczne w lesie otaczającym wyrobisko.

Obecność licznych spękań ciosowych i tektonicznych oraz powszechne występowanie węglanów zarówno w spoiwie, jak i w otoczakach sprzyjały rozwojowi procesów krasowych. Formy krasowe można znaleźć w ścianach górnego poziomu kamieniołomu, gdzie są widoczne liczne szczeliny (ryc. 8), kanały i kominy krasowe, wypełnione wiśniowoczerwonym lub brązowoczerwonym, piaszczystym iłem. Zdaniem Urbana $(2007,2013)$ powstały one w wyniku kenozoicznych (paleogeńsko-neogeńskich) procesów krasowych. Odmienne stanowisko w kwestii wieku form krasowych prezentuje Wierzbowski (1997), który uważa, że był to proces postwaryscyjski.

\section{WALORY GEOEDUKACYJNE I GEOTURYSTYCZNE KAMIENIOLOMU ZYGMUNTÓWKA}

Georóżnorodność oraz wielowiekowa historia eksploatacji, a także walory naukowe i dydaktyczne czynią z kamieniołomu Zygmuntówka wyjątkowe geostanowisko (por. Kozłowska, 2012; Barcicki, Sawicki, 2014). Posługując się prostymi, uniwersalnymi kryteriami, zaproponowanymi przez Wimbledona i in. (2001) oraz Reynarda (2004), autorzy podjęli próbę waloryzacji tego stanowiska (tab. 2). Stosunkowo wysoka punktacja, jaką ono uzyskało (11 punktów - patrz tab. 2), wskazuje na duży potencjał geoedukacyjny i geoturystyczny kamieniołomu. Dlatego też jest on postrzegany jako atrakcja turystyczna regionu świętokrzyskiego (Wołoszyńska, Wołoszyński, 2010) i jest uwzględniany na trasach wycieczek w rejonie kielecko-chęcińskim - nie tylko geologicznych (Kotański, 1959, 1968; Stupnicka, Stempień-Sałek, 2001; Malec, 2013). Zwiedzanie kamieniołomu jest również punktem programu zjazdów geologicznych i konferencji terenowych, organizowanych w Górach Świętokrzyskich (Tomczyk i in., 1962; Rubinowski, Szlagowski, 1981; Kuleta i in., 2007; Fijałkowska-Mader, 2010). Walory kamieniołomu docenili także Kozioł i in. (2003), którzy zasugerowali utworzenie $\mathrm{w}$ nim ścieżki edukacyjnej i bazy namiotowej. Nie można także pominąć walorów krajobrazowych kamieniołomu Zygmuntówka (ryc. 4). Chociaż cała Czerwona Góra jest pokryta lasem, to obecność wyrobiska czyni w tej pokrywie wyraźną przerwę, dzięki której z korony kamieniołomu wciąż roztacza się widok w kierunku zamku w Chęcinach i wschodniej części Doliny Chęcińskiej.

\section{PODSUMOWANIE}

Kamieniołom Zygmuntówka charakteryzuje się dużą georóżnorodnością, co czyni go atrakcyjnym miejscem zarówno dla celów dydaktycznych, jak i szeroko rozumianej geoedukacji. Zróżnicowany petrograficznie skład zlepieńców, bogata, wieloetapowa mineralizacja, zjawiska tektoniczne i krasowe, unikatowe wartości złożowe (tab. 1, ryc. 9) oraz walory historyczno-kulturowe (tab. 2) sprawiają, że jest to stanowisko o randze regionalnej. Dodatkowym atutem jest położenie kamieniołomu w pobliżu drogi 
Tab. 2. Waloryzacja stanowiska geologicznego kamieniołom Zygmuntówka (kryteria wg Wimbledon i in., 2001 i Reynard, 2004) Table 2. Valorization of the geosite Zygmuntówka (Sigismundus) quarry (criteria after Wimbledon et al., 2001 and Reynard, 2004)

\begin{tabular}{|c|c|c|}
\hline $\begin{array}{l}\text { Znaczenie } \\
\text { Importance }\end{array}$ & $\begin{array}{l}\text { Kryterium } \\
\text { Criterion }\end{array}$ & $\begin{array}{c}\text { Punktacja } \\
\text { Score } \\
\left(0,1^{*}\right)\end{array}$ \\
\hline \multirow{5}{*}{$\begin{array}{l}\text { Naukowe } \\
\text { Scientific }\end{array}$} & Integralność (kompletność obiektu) / Integrity (site completeness) & 1 \\
\hline & Reprezentatywność (w skali regionu lub kraju) / Representativeness (regional or countrywide) & 1 \\
\hline & Unikatowość (w skali regionu, kraju lub świata) / Rareness (regional or countrywide) & 1 \\
\hline & Czytelność procesów geologicznych / Visibility of the geological processes & 1 \\
\hline & Rozpoznanie naukowe (literatura) / Scientific background (literature) & 1 \\
\hline \multirow{4}{*}{$\begin{array}{l}\text { Użytkowe } \\
\text { Utilitarian }\end{array}$} & Dostępność / Accessibility & 1 \\
\hline & Widoczność / Visibility & 1 \\
\hline & Przydatność dla edukacji / Importance for education & 1 \\
\hline & $\begin{array}{l}\text { Podatność na zniszczenie (przez uczniów, studentów, turystów) } \\
\text { Damage susceptibility (by students or tourists) }\end{array}$ & 0 \\
\hline \multirow{3}{*}{$\begin{array}{l}\text { Estetyczne } \\
\text { Aesthetic }\end{array}$} & Widokowość / Panoramic quality & 1 \\
\hline & Kolorystyka / Colour diversity & 1 \\
\hline & Naturalność / Naturalness & 0 \\
\hline \multirow{3}{*}{$\begin{array}{l}\text { Kulturowe } \\
\text { Cultural }\end{array}$} & Religijne / Religious importance & 0 \\
\hline & Historyczne / Historical importance & 1 \\
\hline & Artystyczne / Artistic importance & 0 \\
\hline $\begin{array}{l}\text { Ranga obiektu** } \\
\text { Geosite rank** }\end{array}$ & \multicolumn{2}{|l|}{ regionalna / regional } \\
\hline
\end{tabular}

* Wartość 1 oznacza, że geostanowisko spełnia dane kryterium / A value of 1 means that the geosite meets the criterion

** Kategorie obiektów - międzynarodowa, krajowa, regionalna, lokalna / Object categories - international, countrywide, regional, local

ekspresowej S7 oraz drogi z Chęcin do Kielc. Pomimo tych niezaprzeczalnych wartości kamieniołom Zygmuntówka nie jest w pełni wykorzystany w promocji regionu kielecko-chęcińskiego (por. Barcicki, Sawicki, 2014). Nie ma też żadnej infrastruktury edukacyjnej bądź turystycznej. Ze względu na wymienione walory geoedukacyjne oraz przyrodnicze warte rozważenia byłoby objęcie tego stanowiska stosowną ochroną prawną, wyznaczenie ścieżki geotursytycznej oraz postawienie tablic informacyjnych. Planując budowę jakiejkolwiek infrastruktury, należy pamiętać, że kamieniołom pełni jeszcze jedna, bardzo istotną rolę - miejsca, z którego wciąż można pozyskiwać zlepieniec zygmuntowski do prac konserwatorskich $\mathrm{w}$ obiektach zabytkowych.

Serdecznie dziękujemy Redaktorowi Naczelnemu Przegladu Geologicznego dr. hab. Wiesławowi Treli oraz Recenzentowi dr. Zbigniewowi Szczepanikowi za liczne uwagi, które w znaczący sposób podniosły jakoś niniejszego tekstu. Badania terenowe były dofinansowane $\mathrm{z}$ grantu przyznanego Karolowi Jewule w konkursie PRELUDIM Narodowego Centrum Nauki (2018/29/N/ST10/02028).

\section{LITERATURA}

ALEXANDROWICZ Z. 2006 - Framework of European geosites in Poland. Nat. Conserv., 62: 63-87.

BARCICKI M., SAWICKI B. 2014 - Zlepieniec zygmuntowski jako zjawisko geologiczne, materiał architektoniczny i atrakcja turystyczna. Logistyka, 3: 340-352.

BEŁKA Z. 1991 - Permian. [W:] Matyja B.A., Radwański A. (red.), Field-Guide of the Geological Excursion to Poland. Institute of Geology, University of Warsaw. Wyd. Uniw. Warsz., Warszawa: 54-61.
CHOROSZEWSKI W. 1893 - Chęcińskie kopalnie i marmurołomy. [W:] Wielka powszechna encyklopedia ilustrowana, t. 11-12: 546-550. Wyd. S. Sikorski, Warszawa.

CZARNIECKI S., KOSTECKA A., KWIATKOWSKI S. 1965 - Horridonia horrida (Sowerby) ze zlepieńców cechsztynu rejonu Gałęzic (Góry Świetokrzyskie). Rocz. Pol. Tow. Geol., 35: 467-475.

CZARNOCKI J. 1916 - Kilka słów o odkryciu utworów karbońskich w Górach Świetokrzyskich. Spraw. Pos. Tow. Nauk. Warsz., 8: 952-975.

CZARNOCKI J. 1923 - Cechsztyn w Górach Świętokrzyskich. Spraw. Pr. Inst. Geol., 2 (1-2): 151-191.

CZARNOCKI J. 1948 - Przewodnik 20. Zjazdu Polskiego Towarzystwa geologicznego w Górach Świętokrzyskich w r. 1947. Rocz. Pol. Tow. Geol., 17: 237-299.

CZARNOCKI J. 1950 - Geologia regionu łysogórskiego w związku z zagadnieniem złoża rud żelaza w Rudkach. Pr. Państw. Inst. Geol.: 404.

CZARNOCKI J. 1952 - Marmury świętokrzyskie. Biul. Państw. Inst. Geol., 80: 27-51.

CZARNOCKI J., SAMSONOWICZ J. 1915 - Nowe dane o utworach cechsztynu w granicach Gór Świętokrzyskich. Spraw. Tow. Nauk. Warsz., 8: 519-549.

FIJAŁKOWSKA-MADER A. 2010 - Stop 11. Czerwona Góra - The Upper Permian conglomerates. [W:] Oliwkiewicz-Miklasińska M., Łaptaś A., Trela W., Stempień-Sałek M., Masiak M. (red.), CIMP Poland 2010 General Meeting, September $16^{\text {th }}-19^{\text {th }}$ Guidebook of the Holy Cross Mountains field trip. Inst. Nauk Geol. PAN, Warszawa: 55.

GĄGOL J., KRÓL P., URBAN J. 2017 - Kartki z dziejów „Marmurów Kielckich". Kiel. Tow. Nauk., Kielce.

GĄGOL J., KRÓL P., URBAN J. 2020 - Złoża i kopalnie eksploatowane przez „Marmury Kielckie”. [W:] Gówka J., Szczepański J. (red.), Z dziejów Marmurów Kieleckich (1876-2016). Kiel. Tow. Nauk., Kielce: 137-207.

GŁAZEK J., ROMANEK A. 1978 - 1. Jaworznia. [W:] Piątkowski T.S., Wagner R. (red.), Symp. Centr. Europ. Permian. Guide of Excur., Part 2. Zechstein of the Holy Cross Mts. Państw. Inst. Geol., Warszawa: 41-49. GÜRICH G. 1896 - Das Palaeozoicum im Polnischen Mittelgebirges, Breslau.

JENIKE L. 1878 - Marmury kieleckie. Tygodnik Ilustrowany, 5 (107): $24-25,29,32$. 
JEWUŁA K., TRELA W., FIJAŁKOWSKA-MADER A. 2020 - The Permian-Triassic boundary in continental sedimentary succession at the SE margin of the Central European Basin (Holy Cross Mountains, Poland). Geol. Magazine, 157: 1767-1780.

JEWUŁA K., TRELA W., FIJAŁKOWSKA-MADER A. 2021 - Sedimentary and pedogenic record of seasonal humidity during the Permian-Triassic transition on the SE margin of Central European Basin (Holy Cross Mountains, Poland). Palaegeogr., Palaeoclim., Palaeoecol.: 1-25, https://doi.org/10.1016/j.palaeo.2020.110154.

KAŹMIERCZAK J. 1967 - Morphology and palaeoecology of the productid Horridonia horrida (Sowerby) from Zechstein of Poland. Acta Palaeont. Pol., 12: 239-260.

KONTKIEWICZ S. 1910 - Marmury kieleckie. Ziemia. Tygodnik Krajoznawczy Ilustrowany, 22: 343-346.

KOSTECKA A. 1962 - Charakterystyka zlepieńców cechsztyńskich synkliny gałęzicko-bolechowickiej (Góry Świętokrzyskie). Kwart. Geol., 6: 416-435.

KOSTECKA A. 1966 - Litologia i sedymentacja cechsztynu synkliny gałęzicko-bolechowickiej. Pr. Geol. Kom. Nauk Geol. PAN, Oddz. w Krakowie, 38: 1-84.

KOTAŃSKI Z. 1959 - Przewodnik geologiczny po Górach świętokrzyskich, cz. 1. Wyd. Geol., Warszawa.

KOTAŃSKI Z. 1968 -Z plecakiem i młotkiem przez Góry Świętokrzyskie. Wyd. Geol., Warszawa.

KOWALCZEWSKI Z., RUP M. 1989 - Cechsztyn w Górach Świętokrzyskich. Biul. Państw. Inst. Geol., 362: 5-35.

KOZIOŁ W., PAWELEC P., CHIDZIK W. 2003 - Koncepcje zagospodarowania wyrobiska kopalni zlepieńca Zygmunówka. [W:] Srodulska-Wielgus J., Wielgus K., Panek R. (red.), Kształtowanie krajobrazu terenów poeksploatacyjnych w górnictwie, AGH i PK, Kraków: 318-330.

KOZŁOWSKA M. 2012 - 3.14. Perm kamieniołomu Zygmuntówka [W: Skompski S. (red.), Góry Świętokrzyskie. 25 najważniejszych odsłonięć geologicznych,Wydz. Geologii UW, Warszawa: 94-97.

KULETA M., ZBROJA S. 2006 - Wczesny etap rozwoju pokrywy permsko-mezozoicznej w Górach Swiettokrzyskich. [W:] Skompski S., Żylińska A. (red.), Procesy i zdarzenia w historii geologicznej Gór Świętokrzyskich. 77. Zjazd Naukowy Polskiego Towarzystwa Geologicznego, Ameliówka k. Kielc, 28-30.06.2006 r. Państw. Inst. Geol.: 174-178.

KULETA M., ROMANEK M., ZBROJA S. 1998 - Stratygrafia i rozwój sedymentacji triasu w obszarze rawsko-gielniowskim. Nar. Arch. Geol. PIG-PIB, Waszawa.

KULETA M., ZBROJA S., NAWROCKI J. 2007 - Stop. IV.1. Zgmuntówka quarry. [W:] Szulc J., Becker A. (red.), Pan-European Correlation of the Epicontinental Triassic $4^{\text {th }}$ Meeting. International Workshop on the Triassic of southern Poland, September 3-8, 2007. Fieldtrip Guide: 64-67, Pol. Geol. Soc., Pol. Geol. Inst., Inst Geol. Sci. Jagiellonian Univ., Kraków.

KUTEK J., GŁAZEK J. 1972 - The Holy Cross Area, Central Poland in the Alpine cycle. Acta Geol. Pol., 22: 603-654.

MALEC J. 2013 - Punkt wycieczkowy 3.2. (GŚ 3.2) Kamieniołom w Czerwonej Górze. [W:] Pieńkowski G., Cwojdziński S., Fijałkowska-Mader A., Krzeczyńska M., Krzywicki T., Malec J., Pacuła J., Pochocka-Szwarc K., Rychel J., Salwa S., Szczepanik Z., Szrek P., Wierzbowski A., Woźniak P., Złonkiewicz Z., Georóżnorodność naszego kraju. Przewodnik wycieczkowy (płyta DVD). Państw. Inst. Geol. - PIB.

MICHALSKI A. 1887 - Krótki zarys geologiczny południowo-wschodniej części guberni kieleckiej. Izw. Geol. Komit., 6: 351-418.

MIGASZEWSKI Z.M, HAŁAS S., DURAKIEWICZ T. 1996. -

Wiek i geneza mineralizacji kalcytowej w Górach Świętokrzyskich w świetle badań litologiczno-petrograficznych i izotopowych. Prz. Geol., 4 258-261.

MIGASZEWSKI Z.M., MADER A. 2019 - The Use of Museum Collection for Studying the Origin of "Rose-Like" Calcite in the Holy Cross Mountains (South-Central Poland). Geoheritage, 11: 1307-1314.

OTERMAN S. 1980 - Stare i nowe dzieje eksploatacji i obróbki wapien pińczowskich oraz marmurów kieleckich. Pińcz. Zakł. Kamienia Bud., Pińczów.

PUSCH J.B. 1836 - Geologiczny opis Polski oraz innych krajów na północ od Karpat położonych. Stuttgart i Tybinga. VII Górn.-Hutn. Oddz. Warsz. Tow. Pop. Ros. Przem. Handlu.

RAJCHEL J. 2005 - Kamienny Kraków. Uczelniane Wyd. Naukowo-Dydaktyczne, Kraków.

REYNARD E. 2004 - Geosite. [W:] Goudie A.S. (red.), Encyclopedia of geomorphology, vol. 1. Rotledge, London.

ROEMER F. 1870 - Geologie von Oberschlesien. Breslau.
RUBINOWSKI Z. 1971 - Rudy metali nieżelaznych w Górach Świętokrzyskich i ich pozycja metalogeniczna. Biul. Inst. Geol., 247: 1-166. RUBINOWSKI Z. 1978 - Permian deposits in South-western part of the Holy Cross Mts. [W:] Piątkowski T.S., Wagner R. (red.), Symp. Centr. Europ. Permian. Guide of Excur., Part 2. Zechstein of the Holy Cross Mts. Państw. Inst. Geol.: 20-40.

RUBINOWSKI Z., SZLAGOWSKI A. 1981 - Problem II. Punkt 3. Sitkówka-Czerwona Góra. Marmurołom Zygmuntówka; zlepieńce permu. [W:] Przewodnik 53. Zjazdu PTG, Kielce, 6-8 września 1981. Wyd. Geol., Warszawa: 166-169.

SIEMIRADZKI J. 1922 - Geologia ziem polskich. T. I, Lwów: 535.

SOBOLEW D. 1911 - O famennskom jaruse Kelecko-Sandomirskogo Kriazha. Geol. Miner. Ross., 13 (1-2): 35-41.

STUPNICAK E., STEMPIEŃ-SAŁEK M. 2001 - Poznajemy Góry Świętokrzyskie. Wycieczki Geologiczne. Wyd. Nauk. PWN, Warszawa

SZANIAWSKI H. 1963 - Próba nowego podziału cechsztynu synkliny gałęzickiej. Kwart. Geol., 7: 510-511.

SZULC J. 2015 - Posthercyńska mobilność tektoniczna regionu świętokrzyskiego w zapisie sedymentologicznym utworów triasu i permu - diagnoza, Część 2. [W:] Skompski S. (red.), Ekstensja i inwersja powaryscyjskich basenów sedymentacyjnych -84 . Zjazd Naukowy Pol. Tow. Geol, Chęciny, 9-11 września 2015 r. Mat. konfer. Państw. Inst. Geol.-PIB: $17-27$.

SZULCZEWSKI M. 1995 - Depositional evolution of the Holy Cross Mts., Poland in the Devonian and Carboniferous - a review. Geol. Quart., 39: 471-488.

ŚWIĘCICKI H. 1874 - Opis marmurów krajowych, mianowicie przesłanych na wystawy w Moskwie i Wiedniu. Pamiętnik Kielecki na rok zwyczajny 1874 : 47-55.

TOMCZYK H., TOMCZYKOWA E., PAJCHLOWA M. $1962-$ Wycieczka II B. [W:] Żakowa H. (red.), Przewodnik 35. Zjazdu Polskiego Towarzystwa Geologicznego, Kielce 16-19 września 1962. Pol. Tow. Geol.: 1443-152.

URBAN J. 2007 - Permian to Triassic paleokarst of the Świętokrzyskie (Holy Cross) Mts., Central Poland. Kwart. AGH, Geologia, 33: 5-50.

URBAN J. 2013 - Zapis lądowych etapów historii geologicznej Gór Świętokrzyskich w osadach i formach krasowych - wybrane przykłady. Biul. Państw. Inst., Geol., 454: 77-102.

WAGNER R. 1988 - Ewolucja basenu cechsztyńskiego w Polsce. Kwart. Geol., 32: 33-52.

WAGNER R. 1994 - Stratygrafia osadów i rozwój basenu cechsztyńskiego na Niżu Polskim. Pr. Państw. Inst. Geol., 146.

WARDZYŃSKI M. 2011 - The Quarries, the "Marble" and the Centre of Stonemasonry and Sculpture in Chęciny Turing the Modern Era, in the former Commonwealth of Two nations. [W:] Van Belle J.-L. (red.), Actes du 17 e Colloque International de Glyptographie à Cracovie, 5-9 julliet 2010: 379-412.

WELKE A. 1873 - Marmury powiatu kieleckiego. Gazeta Kielecka, 27: 106-107, 28: 110-111.

WIERZBOWSKI H. 1997 - Regionalne interpretacje geologiczne na podstawie badań pstrego piaskowca z wypełnień krasowych okolic Chęcin. Prz. Geol., 45: 707-710.

WIMBLEDON W.A.P., ISHCHENKO A.A., GERASIMENKO N.P., DRANDAKI I., KARIS L.O., SUOMINEN V., JOHANSSON C.E., FREDEN C. 2001 - Geosites - an IUGS initiative: science supported by conservation. [W:] Barettino D., Wimbledon W.A.P., Gallego E. (red.), Geological heritage: its conservation and management. III Intern. Symposium ProGEO, Madrid (Spain): 69-95.

WOŁOSZYŃSKA E., WOŁOSZYŃSKI M. 2010 - Góry Świętokrzyskie. Przewodnik turystyczny. Wyd. Muza SA, Warszawa.

ZBROJA S., KULETA M., MIGASZEWSKI Z.M. 1998 - Nowe dane o zlepieńcach z kamieniołomu „Zygmuntówka” w Górach Świętokrzyskich. Biul. Państw. Inst. Geol., 379: 41-59.

ZIEGLER P.A. 1989 - Evolution of Laurussia. Kluvier Acad. Publ., Dordrecht, Boston, London

ŻUK T., MAŁOLEPSZY Z., SZYNKARUK E. 2018 - Analogue GPR study of the Permian fanglomerates from Zygmuntówka Quarry near Chęciny, Holy Cross Mountains, southern Poland, for construction of a training image for multiple point simulations. Geol. Quart., 62: $755-766$.

Praca wpłynęła do redakcji 27.09.2021 r. Akceptowano do druku 22.11.2021 r. 


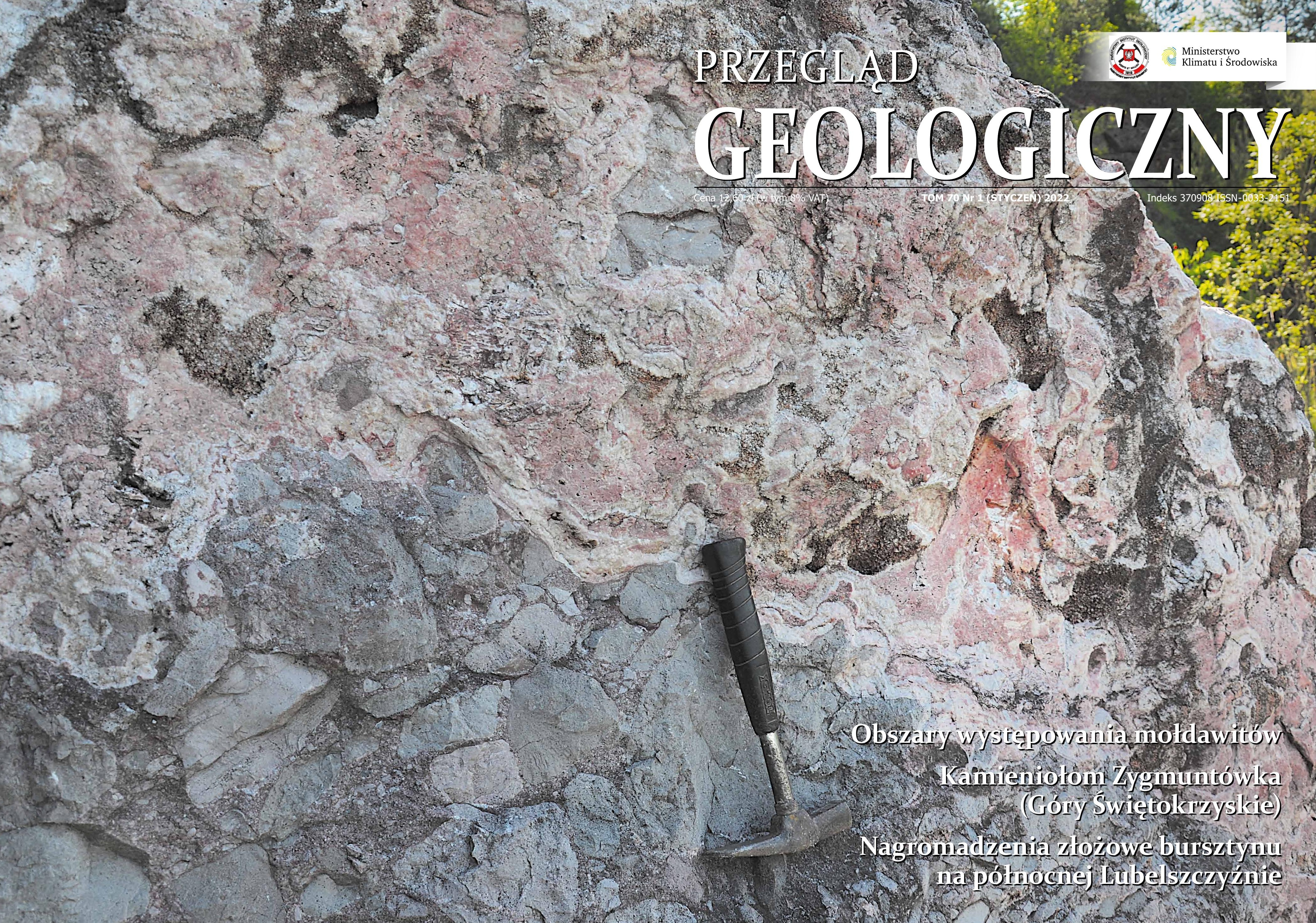


Zdjęcie na okładce: Żyła kalcytu różanka w zlepieńcu zygmuntowskim na Górze Czerwonej (Góry Świętokrzyskie) - zobacz artykuł K. Jewuły i in. na str. 25. Fot. J. Malec

Cover photo: Vein of rose-like calcite cutting the conglomerate on the Czerwona Mountain (Holy Cross Mountains) - see article by K. Jewuła et al. on p. 25. Photo by J. Malec 